\title{
POLA PEWARISAN BUDAYA SYAIR MELAYU \\ DI LOMBOK TIMUR (KAJIAN SEJARAH BUDAYA)
}

\author{
${ }^{1}$ Muhammad Shulhan Hadi \\ ${ }^{1}$ Universitas Hamzanwadi \\ shulhan@gmail.com
}

\begin{abstract}
Abstrak
Tujuan penelitian ini berusaha menggali dan mengnalisa peranan Syair Melayu Islam dalam budaya Sasak di Lombok Timur khususnya di desa Rumbuk. Metode penelitian yang digunakan ialah metode sejarah. Hasil penelitian menunjukkan bahwa (1) Proses masuknya Syair Melayu Islam bersamaan dengan proses masuknya Islam yang terus berkembang sampai saat ini; (2) Nilai yang terkandung dari beberapa kitab Syair Melayu Islam secara umum sangat berperan dan dapat mempengaruhi nilai keberagamaan masyarakat di desa Rumbuk; (3) Pewarisan budaya Syair Melayu Islam dilakukan melalui proses internalisasi, adapts, sosialisasi, serta enkulturasi atau pembudayaan.
\end{abstract}

Kata Kunci: Pola Pewarisan, Syair Melayu Islam.

\section{PENDAHULUAN}

Pelaksanaan pembangunan di daerah Nusa Tenggara Barat khususnya pembangunan fisik, telah menampakkan hasilnya. Terlepas dari tingkat keberhasilan pembangunan fisik di daerah ini, secara nyata tampak adanya berbagai kemajuan yang cukup berarti. Komunikasi dengan dunia luar semakin terbuka dan demikian lancarnya. Pengaruh budaya asing, disadari ataupun tidak seolah-olah tanpa kendala masuk ke rumah-rumah penduduk, baik di desa maupun di kota melalui berbagai media massa, media cetak maupun media elektronik.

Masuknya kebudayaan asing tidak dapat dipungkiri, selain perhubungan antar suku bangsa dengan tujuan khusus seperti pariwisata, kunjungan budaya dan misi sosial politik lainnya, hampir dapat dipastikan bahwa masyarakat pada hakikatnya cendrung mengadakan hubungan sosial dengan sesamanya. Berbagai perubahan dalam masyarakat dalam kajian Antropologi disebut proses akulturasi. Akulturasi dapat diartikan sebagai suatu proses sosial yang timbul apabila suatu kelompok manusia dengan suatu kebudayaan tertentu sedemikian rupa dipengaruhi oleh unsur-unsur suatu kebudayaan lain sehingga unsur-unsur lain itu diterima dan disesuaikan dengan unsurunsur kebudayaan sendiri tanpa menyebabkan hilangnya identitas asli. Berhubungan dengan kehidupan masyarakat yang esensinya selalu berubah, terkadang budaya yang dulunya terakulturasi dengan budaya lokal, akan menjadi terancam oleh adanya budaya 
dari luar atau mungkin juga budaya yang pernah terakulturasi tersebut nilainya berkurang pada masyarakat sekitar.

Pernyataan di atas tidaklah sekedar opini yang menyangkut perubahan, melainkan realitas sosial yang memiliki nilai tersendiri untuk dikaji. Hal ini penting, karena kenyataannya kehidupan sosial adalah dinamis, karena itu perubahan selalu terjadi, walaupun pada taraf tertentu sebagian orang tidak menginginkannya. Namun, satu hal yang perlu dipahami sebagaimana dikatakan Williams (Kuntowijoyo, 1999) bahwa eksistensi budaya ditentukan tiga komponen pokok, yaitu lembaga-lembaga budaya, isi budaya dan efek budaya atau norma-norma.

Lembaga budaya menanyakan siapa menghasilkan produk budaya, siapa mengontrol, dan bagaimana kontrol itu dilakukan, isi budaya menanyakan apa yang dihasilkan atau simbol-simbol apa yang dihasilkan; dan efek budaya menanyakan konsekuensi apa yang diharapkan dari proses budaya itu (Kuntowijoyo, 1999: 5). Mencermati apa yang dikatakan Williams ini nyatalah bahwa eksistensi budaya tergantung dari lembaga budaya tersebut. Lembaga budaya itu sendiri tidak lain adalah masyarakat yang menjalankannya.

Apabila proses sosialisasi, enkulturasi dan lain sebagainya tidak berjalan efektif pada masyarakat yang merupakan lembaga budaya di atas, maka inilah yang terkadang menyebabkan terjadinya perubahan pada generasi selanjutnya. Sebagai contoh kecil saja, beberapa hal yang merupakan tradisi, norma-norma, adat-istiadat dan lain sebagainya, karena perkembangan pemikiran hal ini harus direlakan berubah, karena memang kedinamisan itu sendirilah yang menyebabkan terjadinya demikian.

Berbicara mengenai tradisi khususnya di Pulau Lombok, mungkin sampai saat ini bisa dikatakan masih menunjukkan adanya eksistensi walaupun seperti dikatakan di atas tidak menutup kemungkinan karena perubahan pandangan pada generasi saat ini dan yang akan datang beberapa tradisi akan semakin berkurang jika tidak dipelihara dengan baik. Misalnya saja salah satu tradisi yang telah lama di enkulturasikan dalam masyarakat Sasak berupa 'Syair Melayu Islam', namun karena adanya proses sosialisasi dan enkulturasi yang kurang baik tadi pada masyarakat tradisi ini mulai berkurang. Walaupun, disebagian tempat, keberadaan tradisi ini terus-menerus dilestarikan masyarakat sebagai salah satu dari budaya mereka. Salah satu kawasan yang terusmenerus melestarikan Syair Melayu Islam ini misalnya kita dapatkan di Lombok Timur, yang mana hal ini proses enkulturasinya untuk saat ini dirasakan mulai berkurang. Karena itu penting rasanya gejala-gejala ke arah penurunan tersebut untuk dicermati. 
Kemampuan budaya Syair Melayu Islam ini untuk bertahan diantara budaya lainnya yang berkembang pada masyarakat desa Rumbuk akhir-akhir ini terutama pada generasi mudanya merupakan suatu proses enkulturasi budaya yang penting untuk dicermati, bukan hanya aspek luar seperti kegunannya sebagaimana yang dilakukan saat ini, dalam arti kegunaan praktis yang dirasakan. Kegunaan praktis ini (kegunaan yang dirasakan masyarakat secara langsung dari Syair Melayu Islam) bisa dikatakan sebagai sebab langsung (direct cause) dari bertahannya Syair Melayu Islam tersebut di desa Rumbuk. Selain itu juga, jelas didalamnya terdapat faktor tidak langsung (indirect cause) sehingga budaya syair melayu Islam ini bisa bertahan sampai saat ini, dan bukan hanya itu kegunaannya penting bagi masyarakat.

\section{SYAIR MELAYU ISLAM}

Sya'ir berasal dari bahasa Arab yaitu syu'ur yang berarti perasaan, kata syu'ur berkembang menjadi kata syi'ru yang berarti puisi dalam pengertian umum. Syair dalam kesusastraan Melayu merujuk pada pengertian puisi secara umum. Akan tetapi, dalam perkembangannya syair tersebut mengalami perubahan dan modifikasi sehingga menjadi khas Melayu, tidak lagi mengacu pada tradisi sastra syair di negeri Arab (Fang,1993: 201). Kata syair juga sering dipakai dikalangan umat Islam Indonesia dengan digabungkan pada kata Islam. Sehingga menjadi syiar Islam. Syiar Islam diartikan sebagai kemuliaan dan kebesaran. Secara umum syiar Islam merupakan tanda, simbol atau selogan Islam yang tampak pada ibadah yang dirayakan secara besarbesaran seperti shalat Idul Adha dan Shalat Idhul Fitri di lapangan terbuka. Selain itu juga pada kegiatan keIslaman yang dilakukan masyarakat Islam seperti perayaan maulid Nabi Muhammad dan perayaan Isra' dan Mi'raj Nabi Besar Muhammad SAW (Kuntowijoyo, 1991: 39).

Syair merupakan ungkapan perasaan seseorang terhadap orang lain atau terhadap alam semesta dan juga perasaan manusia terhadap kholiq atau pencipta alam semesta yang dituangkan dalam bentuk tulisan. Tulisan itu adalah sajak-sajak, hikayathikayat yang berdasarkan pengalaman dari penyair (Syahbana, 1985: 46). Syair Melayu yang menggunakan bahasa jawi pertama kali berkembang pada abad ke 14 dan mencapai puncaknya pada abad 17 di kerajaan Aceh berkat dorongan adanya kegiatan ahli-ahli pikir keagamaan, sastrawan-sastrawan terkenal yang menulis kitab-kitab Jawi yang isinya mengandung berbagai keilmuan dalam berbagai bidang keagamaan, 
kesusastraan, kesejarahan, hukum dan lainnya. Di antara ahli-ahli pikir keagamaan di Aceh ialah Hamzah al-Fansuri, Syamsuddin al-Sumatrani/ Pasai, Bukhari al-Jauhari, Nuruddin al- Raniri, Abdul Rauf al-Singkili dan sebagainya. Hamzah Fansuri pernah mengatakan bahwa ia banyak menterjemahkan kitab-kitab dalam bahasa Arab dan Parsi ke dalam bahasa Jawi (Melayu) untuk bangsaanya yang tidak mengenal bahasa Arab dan Parsi (Al-Attas, 1968: 44-46; Tjandrasasmita, 1993:194).

Naskah-naskah dari zaman pra Islam yang ditulis dalam huruf-huruf daerah misalnya bahasa jawi, umumnya ditulis oleh para pujangga. Tetapi naskah-naskah yang ditulis dalam hurup jawi, baik dalam bahasa Melayu maupun dalam bahasa daerah yang lain, banyak yang menunjukkan bahwa penulisannya atau asalnya bukanlah dari keraton. Kenyataan ini memperlihatkan bahwa Islam mendorong meluasnya peradaban tulis menulis dalam masyarakat. Dalam sejarah tercatat bahwa Nabi Muhammad SAW membebaskan tawanan-tawanan perang yang bisa membaca dan menulis asal mereka mau mengajarkan kepandaiannya itu kepada para prajurit Islam paling tidak sepuluh orang (Mustafa, 1964: 12-13).

Dengan demikian dapat dipahami bahwa pemakaian huruf jawi diperluas pemakaiannya, bukan hanya untuk hal-hal yang bertalian dengan pengetahuan agama, melainkan juga untuk hal-hal lain termasuk karya sastra, cerita-cerita yang semula hanya dikenal secara lisan juga ditulis dengan adanya huruf jawi. Karya-karya yang demikian ini dapat digolongkan ke dalam kelompok pra Islam. Karya-karya yang digolongkan ke dalam kelompok "Zaman Islam" adalah karya-karya sastra yang secara jelas memperlihatkan pengaruh atau alam pikiran Islami. Dalam garis-garis besarnya karya-karya itu dapat di golongkan menjadi dua bagian, yaitu: pertama, karya-karya sastra yang bersifat sufistik seperti karya Hamzah Fanshuri dari Aceh dalam bahasa melayu (abad-17), karya-karya yang demikian ini ditulis oleh para ulama Islam yang mendalami pengetahuannya tentang Islam dan mempunyai kecendrungan terhadap Sufisme. Sedangkan golongan yang kedua adalah karya sastra yang memperlihatkan pengaruh sastra Islam baik dari bahasa Arab maupun bahasa Persia atau lainnya.

Karya-karya yang demikian itu antara lain seperti: kisah-kisah Seribu Satu Malam (Alfu Lailah Wa Lailah), kisah-kisah para nabi dan hikayat Amir Hamzah (Hamzah, 1982: 54). Karya sastra ini sering dibuat dan dipertunjukkan dalam bentuk "tembang" ia banyak mendapat pengaruh melayu, tetapi diperdengarkan dengan irama (lagu) yang diberi ciri khas sasak. Syair mempunyai tiga unsur penting, yaitu seluruh kitab Syair Melayu Islam dan hikayat sebagai acuan untuk si pembaca atau penyair. 
Seorang penyair atau pujangga, seorang penterjemaah ke dalam bahasa Sasak atau yang menirukan bacaan tetapi diramalkan dan kemudian pada saat tertentu dinyanyikan bersama.

Kitab-kitab Jawi karya para ulama di Aceh memiliki pengaruh yang bukan hanya ke daerah-daerah Kerajaan Islam di Sumatera, tetapi juga sampai ke daerahdaerah Kerajaan Islam di kepulauan Indonesia lainnya: Jawa, Nusa Tenggara Barat, Maluku, Sulawesi, dan Kalimantan. Bila sebutan tulisan Jawi yang dipergunakan erat kaitannya dengan penulisan bahasa Melayu termasuk bahasa Melayu lokal (tempatan), maka di Jawa dan Sunda tulisan Arab yang digunakan untuk menulis kedua bahasa itu disebut tulisan Pegon. Mengenai proses masuk dan berkembangnya Syair Melayu Islam atau berhikayat di pulau Lombok, setidaknya ada dua pendapat yang dapat dikemukakan. Masing-masing pendapat ini diperkuat oleh bukti-bukti yaitu:

\section{SYAIR MELAYU ISLAM MASUK DARI MELAYU LANGSUNG}

Arab Melayu adalah aksara utama dalam penyebaran bahasa Melayu ke seluruh wilayah Nusantara: yang penggunaannya dimulai seiring dengan kedatangan agama Islam ke kepulauan Melayu ini. Disebut Arab Melayu, karena merupakan huruf-huruf Arab yang sengaja diubah untuk mewakili bunyi bahasa Melayu. Seni penulisan ini juga dikenal dengan nama Jawi, Jawoe, Kawung, untuk tulisan Arab Melayu yang berbahasa Jawa disebut Pegon. Sedangkan sebutan tulisan Arab Melayu di pulau Lombok disebut tulisan Jawi.

Khasanah naskah beraksara arab dalam bahasa daerah di setiap kawasan yang beragama Islam seperti Aceh, Palembang, daerah Riau, seluruh kepulauan Madura, Jawa, Lombok, dan pesisir Kalimantan sangat berlimpah. Di samping banyak sekali naskah berbahasa Arab, baik karangan ulama Indonesia maupun interpretasi dari karya ulama Timur Tengah (PaEni. 309: 2009). Menurut Rukmi, (2004: 185) naskah Melayu juga terdapat di NTB yaitu Lombok dan Bima. Naskah-naskah di Lombok yang berbahasa Melayu diantaranya Isra' Mi'raj, Hikayat Abu Nawas, Cerita-Certia Nabi Muhammad, hikayat nabi Yusuf dan lain sebagainya. Sedangkan di Bima itu ada naskah tentang Bo, Do'a, Filsafat, Hikayat, Silsilah, Surat Keputusan dan lain sebagainya.

Karena pengaruh islamisasi dan hubungan perdagangan, pada pertengahan abad ke 16 pengaruh Melayu mulai masuk ke pulau Lombok yang dibawa oleh ulama-ulama dari Sumatera yaitu Jatiswara, kiai Serimbang dan Enem beret. Ketiga ulama ini pernah 
mengembara ke pulau Lombok untuk menyebarkan agama Islam kepada masyarakat Lombok (Solichin. 1979:33).

\section{Syair Melayu Islam masuk ke pulau Lombok dengan perantara}

Masuknya Syair Melayu Islam dengan perantara artinya bahwa Syair Melayu ini tidak langsung datang dari Melayu namun, lebih dulu singgah di daerah lain seperti di Sulawesi, Bima dan lain sebagainya. Karena hubungan dagang dan islamisasi kemudian syair Melayu ini kemudian masuk ke pulau Lombok. Agar Syair Melayu Islam mudah diterima dan diimplementasikan oleh masyarakat dalam kehidupan sehari-hari di pulau Lombok dan desa Rumbuk pada khususnya, maka setidaknya ada dua cara yang dilakukan sebagai proses adaptasi yaitu:

\section{Penambahan Irama Khas Sasak}

Syair Melayu Islam merupakan syair yang di ambil dari beberapa kitab yang menggunakan bahasa Arab Melayu seperti kitab Daqoiqul Ahbar, Kasful Asror, Al Jawahir, Al Kurtubi, Nur Muhammad, Kisasul Anbiya dan lain sebagainya. Syair Melayu Islam ini pada awalnya hanya dibaca biasa dan dilagukan, namun dengan semakin berkembangnya Islam di pulau Lombok dan semakin luas penggunaan Syair Melayu Islam maka Syair Melayu Islam ini dimodifikasi dan ditambah dengan beberapa tambahan seperti yang ada di desa Rumbuk sekarang.

Agar agama Islam dan Syair Melayu Islam mudah diterima dan dipahami oleh masyarakat maka Syair Melayu Islam yang merupakan media yang dipergunakan sebagai media dakwah di modifikasi atau diadaptasikan dengan ciri khas masyarakat Sasak yaitu dengan menambahkan irama dan lagu khas Sasak dalam proses pembacaan Syair Melayu Islam kemudian diterjemahkan atau ditafsirkan ke dalam bahasa Sasak.

\section{Syair Melayu Islam Disesuaikan Dengan Upacara Adat}

Dalam budaya masyarakat terdapat beberapa upacara-upacara adat atau dikenal dengan daur hidup yang masih berlaku sampai sekarang misalnya upacara kelahiran, cukur rambut bayi (Ngurisang), Khitanan (Nyunatang), menikah (Merariq), kematian dan lain sebagainya. Di samping dengan memodifikasi Syair Melayu Islam, agar semakin memudahkan Islam berkembang di masyarakat maka para muballigh menyesuaikan teks Syair Melayu Islam dengan konteks yang ada di dalam masyarakat.

\section{PERANAN SYAIR MELAYU ISLAM DALAM MASYARAKAT}

Berbicara tentang peranan Syair Melayu Islam tentunya kita akan berbicara mengenai nilai-nilai yang terkandung dalam Syair Melayu Islam tersebut. serta 
bagaimana penerimaan masyarakat sebagai konteks bermuaranya nilai-nilai Syair Melayu Islam tersebut. Sehingga bisa dikatakan nilai-nilai yang terkandung dalam Syair Melayu tersebut diadaptasi dalam konteks kehidupan masyarakat.

Berdasarkan hal itu, identifikasi nilai-nilai yang terkandung dalam teks dan konteks (masyarakat) perlu diidentifikasi. Hal ini penting untuk dapat menganalisa peranan Syair Melayu Islam itu sendiri terhadap masyarakat Sasak di desa Rumbuk. Setidaknya ada dua peranan Syair Melayu Islam yang dapat dilihat dalam kehidupan masyarakat desa Rumbuk setelah abad XX yaitu:

\section{Syair Melayu Islam Sebagai Media Penanaman Nilai Keagamaan}

Sebelum abad XX, Syair Melayu Islam digunakan sebagai media penyebaran Islam pada masyarakat Sasak di pulau Lombok sekaligus sebagai media pengajaran agama Islam oleh para muballigh. Namun setelah abad XX, dengan semakin berkembangnya masyarakat dan semakin banyaknya lembaga-lembaga pendidikan terutama lembaga pendidikan agama, peran Syair Melayu Islam yang pada awalnya sebagai media penyebaran dan pengajaran agama Islam mulai bergeser digantikan perannya oleh lembaga-lembaga pendidikan agama tersebut.

Setelah terjadi perubahan di dalam masyarakat, Syair Melayu Islam tidak lagi digunakan sebagai media penyebaran dan pengajaran agama di dalam masyarakat Sasak khususnya di desa Rumbuk. Peran Syair Melayu Islam bergeser menjadi media penanaman nilai-nilai keagamaan. Syair Melayu Islam yang diambil dari beberapa kitab Melayu ini, terkandung berbagai nilai atau value di dalamnya tergantung kitab itu sendiri. Sebagai contoh, di dalam kitab Daqoiqul ahbar yang di dalam dibahas mengenai kematian misalnya keluarnya roh dari jasad, alam kubur, surga, neraka dan lain sebagainya. Sehingga nilai yang terkandung di dalamnya bagaimana seorang manusia sadar dan ingat tentang kematian serta rajin beribadah kepada penciptanya. Jangan hanya disibukkan dengan perkara-perkara dunia dan lupa kepada kewajiban yang sebenarnya yaitu beribadah kepada Allah SWT.

Sedangkan di dalam kitab Kasful asror dibahas mengenai perkawinan, misalnya hak dan kewajiban istri terhadap suami dan hak serta kewajiban suami terhadap istri. Di dalam kitab ini juga dibahas mengenai ciri-ciri wanita yang baik dan balasan bagi wanita yang tidak taat kepada suaminya. Sehingga nilai yang terkandung disini yaitu bagaimana seharusnya seorang suami dan istri di dalam menjalankan sebuah rumah tangga serta bagaimana cara seorang istri menjaga dirinya serta harta suaminya ketika suaminya tidak ada di rumah. Di samping itu juga disini dibahas tentang balasan bagi 
istri yang durhaka terhadap suami yaitu gugur kewajibannya untuk menerima nafkah dari suaminya, hal ini diharapkan agar seorang istri selalu taat kepada suaminya. Sehingga diharapkan nilai-nilai keagamaan yang merupakan nilai dasar dan nilai dominan dalam kitab-kitab tersebut bisa mempengaruhi dan diimplementasikan oleh masyarakat dalam kehidupan sehari-hari.

\section{Syair Melayu Islam Sebagai Media Penanaman Nilai Kemasyarakatan}

Peranan Syair Melayu Islam sebagai media penanaman nilai-nilai kemasyarakatan di dalam masyarakat dapat dilihat dalam kehidupan masyarakat misalnya:

\section{Nilai budaya}

Sejalan dengan semakin berkembangnya masyarakat desa Rumbuk, Syair Melayu Islam yang pada awal kedatangannya merupakan media penyebaran dan pengajaran agama Islam yang dilakukan oleh para muballigh, namun dengan seiring berjalannya waktu, Syair Melayu Islam ini kemudian beradaptasi dengan kebudayaan masyarakat yang sudah ada misalnya apa yang disebut dengan upacara daur hidup masyarakat Sasak yaitu upacara dari kematian, perkawinan sampai kematian.

Selain nilai keagamaan yang terkandung dalam kitab-kitab Syair Melayu Islam seperti yang sudah dijelaskan di atas dan nilai budaya yang berkembang di masyarakat termasuk didalamnya bagaimana masyarakat dalam upacara daur hidup terus dipertahankan, mencerminkan bahwa Syair Melayu Islam sendiri dapat mengikat budaya masyarakat yang sudah ada, sehingga budaya masyarakat tetap lestari dan dipertahankan dari generasi ke generasi sampai dengan sekarang.

\section{Nilai keseimbangan}

Nilai keseimbangan yang ada di dalam masyarakat maksudnya di sini adalah keselarasan hubungan antara manusia dengan tuhannya, manusia dengan lingkungannya dan manusia dengan sesama manusia. Nilai-nilai keseimbangan yang memang sudah ada di dalam masyarakat tersebut dipadukan dengan nilai-nilai yang ada di dalam kitab Syair Melayu Islam sehingga nilai keseimbangan tersebut dapat diimplementasikan oleh masyarakat dalam kehidupan sehari-hari.

\section{Nilai Solidaritas/Kebersamaan}

Nilai solidaritas atau kebersamaan maksudnya di sini yaitu kebersamaan dan kerjasama yang terjalin antar individu dengan individu, individu dengan kelompok dan kelompok dengan kelompok yang terdapat pada masyarakat di desa Rumbuk. Hal tersebut dibuktikan dengan masih tingginya solidaritas dan kolektifitas masyarakat 
ketika mengadakan acara-acara seperti ketika ada masyarakat lain yang kebetulan mengadakan acara tertentu maka masyarakat yang lain walaupun tanpa diminta oleh orang yang mengadakan acara, mereka ikut membantu.

Ketika ada masyarakat akan melaksanakan salah satu upacara yang sudah disebutkan di atas, dengan mengundang penyair untuk membacakan Syair Melayu Islam, maka masyarakat berbondong-bondong untuk ikut membantu persiapan dan segala hal yang diperlukan dalam pelaksanaan upacara tersebut. Tingginya nilai solidaritas dan kebersamaan dalam masyarakat desa Rumbuk ini semakin kuat dan terpelihara dengan adanya Syair Melayu Islam.

\section{Nilai Estetika}

Syair Melayu Islam yang merupakan sebuah budaya pasti memiliki nilai keindahan karena di dalamnya memiliki nilai etetika yang sarat dengan berbagai nilainilai. Dengan nilai estetika yang ada di dalam Syair Melayu Islam yang berbaur dengan nilai estetika yang ada dalam konteks masyarakat maka Syair Melayu Islam dalam budaya Sasak di Lombok timur semakin kuat dan terpelihara.

\section{POLA PEWARISAN SYAIR MELAYU ISLAM DI DESA RUMBUK}

Masyarakat desa Rumbuk yang dalam hal ini merupakan lembaga budaya dan merupakan salah satu hal yang terpenting di dalam memelihara eksistensi Syair Melayu Islam tersebut, melaksanakan setidaknya 4 hal dalam menjaga dan terus melestarikan Syair Melayu Islam ini yaitu sebagai berikut:

\section{Proses Adaptasi}

Paling tidak ada dua hal yang dilakukan masyarakat desa Rumbuk di dalam proses mengadaptasi Syair Melayu Islam sehingga syair ini bisa diinternalisasikan ke dalam kehidupan sehari-hari yaitu:

\section{Penambahan Irama Khas Sasak}

Agar Islam lebih cepat diterima di pulau Lombok, khususnya di masyarakat desa Rumbuk, Syair Melayu Islam ini dimodifikasi dan diadaptasi dengan irama khas Sasak. Penambahan irama khas Sasak dalam Syair Melayu Islam ini bukan dengan menambah atau mengurangi isi teks kitab yang dibaca melainkan dengan menambahkan iramairama atau tembang khas Sasak ketika pembacaan Syair Melayu Islam ini kemudian ditafsirkan atau diterjemahkan ke dalam bahasa Sasak oleh penyair.

Syair Melayu Islam biasanya dibaca pada tengah malam sekitar jam 9 atau 10 selama 1 sampai 2 jam, hal ini dikarenakan agar lebih khusu' dan tidak menganggu 
masyarakat yang lain. Syair Melayu Islam ini dibaca dan diperdengarkan dalam irama yang berciri khas Sasak dan pada suatu waktu Syair ini dibaca secara bersamaan. Syair Melayu Islam ini dibaca setidaknya oleh dua orang penyair, yaitu satu orang sebagai pembaca Syair Melayu Islam dan satu orang lagi sebagai penterjemah atau yang menafsirkan Syair Melayu Islam tersebut ke dalam bahasa Sasak. Syair Melayu Islam ini dibaca secara berpasangan antara penyair dan penterjemah karena dalam pembacaan syair itu diperlukan pemahaman dan pengertian diantara penyair dan penterjemah.

Berdasarkan penjelasan di atas, maka modifikasi yang dilakukan untuk penyesuaian dalam hal ini adalah dimasukkannya irama lokal (Sasak), adanya penyair dan penerjemah (seorang yang menjabarkan isi Syair Melayu Islam dengan menggunakan bahasa Sasak). Dua perubahan ini bisa dikatakan sebagai suatu pola penambahan yang dilakukan untuk lebih mendekatkan masyarakat dengan isi dari Syair Melayu Islam tersebut.

\section{Syair Melayu Islam Diterjemahkan Dalam Bahasa Sasak}

Selain dengan menambahkan irama khas Sasak ke dalam Syair Melayu Islam, masyarakat desa Rumbuk juga menterjemahkan Syair Melayu Islam tersebut ke dalam bahasa Sasak. Penerjemahan ini dilakukan pada awalnya selain karena disesuaikan dengan kondisi dan pemahaman masyarakat yang masih awam juga dilakukan untuk mendekatkan masyarakat kepada makna atau isi yang ada di dalam kitab-kitab Syair Melayu Islam tersebut.

Artinya di sini bahwa modifikasi dan adaptasi dalam Syair Melayu Islam ini dilakukan bukan dengan menambahkan atau mengurangi isi Syair Melayu Islam tersebut tetapi dengan ditambahkan irama dan kemudian diterjemahkan ke dalam bahasa Sasak agar masyarakat lebih cepat paham dengan isi yang terkandung di dalam Syair Melayu Islam tersebut.

\section{Proses Internalisasi}

Syair Melayu Islam di desa Rumbuk pada awalnya jelas merupakan sarana penanaman nilai Islam pada masyarakat, artinya bukan milik nenek moyang masyarakat Sasak sebelumnya. Keberadaannya bersamaan dengan perkembangan Islam di Bumi Sasak. Artinya bahwa, pada saat itu Syair Melayu Islam dihadapkan dengan masyarakat yang tidak vakum budaya, sehingga Syair Melayu ini harus bersentuhan dengan budaya yang ada pada masyarakat.

Proses internalisasi Syair Melayu Islam di desa Rumbuk sekaligus sebagai proses edukasi terhadap generasi muda dilakukan dengan memberikan peendidikan 
cultural atau pembelajaran sekali seminggu kepada generasi muda. Hal ini dilakukan sebagai salah satu jembatan kepada generasi selanjutnya untuk dapat memahami Syair Melayu Islam tersebut, sehingga nantinya paling tidak isi yang terkandung di dalamnya dapat diajarkan kepada generasi selanjutnya, terlebih lagi jika anak-anak yang belajar tersebut bisa mengajarkan kembali suatu saat nanti kepada generasinya kemudian.

Proses pembelajaran Syair Melayu Islam di desa Rumbuk biasanya berlangsung pada malam Jum'at setelah anak-anak melakukan shalat magrib secara berjamaah di masjid. Adapun guru yang mengajarkannya adalah para penyair yang sudah dikenal oleh masyarakat. Guru penyair ini tidak mendapatkan gaji dari pemerintah, akan tetapi keikhlasan dari orang tua murid yang belajar Syair Melayu Islam tersebut.

\section{Proses Sosialisasi}

Proses sosialisasi Syair Melayu Islam di desa Rumbuk dilakukan dengan mengadakan semacam pengajian atau pembacaan Syair Melayu Islam di masjid. Biasanya pembacaan Syair Melayu Islam sebagai langkah sosialisasi di dalam masyarakat dilakukan sekali sebulan atau lebih dan semua masyarakat bisa mengikutinya. Biasanya masyarakat membawa serta anak mereka ke masjid untuk mendengarkan pembacaan Syair Melayu Islam tersebut. Kitab yang dibacakan di sini adalah bukan lagi kitab masailah namun kitab yang biasa dibaca apabila ada undangan dari masyarakat seperti kitab Daqoiqul ahbar, Kasful asror, Al jawahir dan lain sebagainya.

Proses inilah yang dilakukan oleh masyarakat desa Rumbuk di dalam melakukan sosialisasi dan sekaligus melestarikan eksistensi Syair Melayu Islam tersebut. Sehingga diharapkan apabila proses tersebut tetap berjalan lancar maka Syair Melayu Islam ini akan tetap bertahan dan lestari walaupun banyak pengaruh dari budaya luar. Di samping itu juga proses sosialisasi ini diharapkan bisa menularkan budaya kepada generasi muda yang notabenenya cepat terkontaminasi dengan budaya di luar budayanya sehingga Syair Melayu Islam ini tetap terjaga dan bertahan dari generasi ke generasi.

\section{Proses Enkulturasi}

Sebagai proses enkulturasi, masyarakat desa Rumbuk melakukan penyesuaian terhadap Syair Melayu Islam dengan upacara-upacara adat atau daur hidup Sasak yang ada di desa Rumbuk misalnya upacara kelahiran, upacara pemotongan rambut atau aqiqah, upacara khitanan, upacara perkawinan, upacara kematian dan lain sebagainya. Penyesuaian teks Syair Melayu Islam dengan konteks yang ada di dalam masyarakat seperti daur hidup itu, sehingga di samping sebagai jalan untuk menanamkan nilai-nilai 
keagamaan yang terkandung di dalam kitab-kitab tersebut, juga menjadi sesuatu yang tidak bisa dipisahkan antara upacara-upacara adat dengan Syair Melayu Islam. Artinya di sini dengan disesuaikannya Syair Melayu Islam dengan konteks masyarakat maka masyarakat merasakan suatu keharusan membaca Syair Melayu Islam apabila ada upacara-upacara adat di dalam masyarakat.

Artinya bahwa, Syair Melayu Islam ini diadaptasi dalam budaya daur hidup Suku Sasak, khususnya yang ada di Desa Rumbuk, sehingga masyarakat lamakelamaan, selain sebagai jalan untuk pemahaman Islam yang lebih baik, atau katakanlah penanaman nilai-nilai keislaman, sekaligus menjadi sesuatu yang melekat dengan adat atau upacara daur hidup masyarakatnya, sehingga masyarakat merasakan adanya sebuah keharusan untuk membaca Syair Melayu Islam ini ketika ritual daur hidup tersebut dilakukan.

\section{DAFTAR PUSTAKA}

Al-Attas, Syed Muhammad Naquib. 1968. The Origin of the Malay Sha'ir. Kuala Lumpur: Dewan Bahasa dan Pustaka.

Ali Syahbana, St. Takdir, 1985. Persepsi Masyarakat Tentang Kebudayaan. Jakarta: Gramedia.

Ali Syahbana, St. Takdir. 1986. Antropologi Baru. Jakarta: Universitas Nasional: Dian Rakyat.

Budiwanti, Erni. 2000. Islam Sasak: Wetu Telu Versus Waktu Lima. Yogyakarta. LKiS.

Fang, Liaw Yock. 1991. Sejarah Kesusastraan Melayu Klasik 2. Jakarta: Erlangga.

Fang, Liaw Yock. 1991. Sejarah Kesusastraan Melayu Klasik I. Jakarta: Erlangga.

Hafiz, Harmain. 2010. Islamisasi Lombok; historiografi dakwah abad XVI.

Hamzah, Amir. 1982. Sastra Melayu Lama dan Raja-Rajanya. Jakarta: Dian Rakyat.

Kesuma, Andi Ima. 2012. Menjahit Laut: Makassar Dan Lombok Dalam Lintas Sejarah Maritim. Makalah Disampaikan Pada Seminar Nasional Hari Nusantara di Kota Mataram hari Minggu 23 Desember 2012.

Koentjaraningrat. 2003. Pengantar Antropologi 1. Jakarta: Rineka Cipta.

Koentjaraningrat. 2010. Sejarah Teori Antropologi. Jilid 2. Jakarta: Universitas Indonesia Press.

Kuntowijoyo. 1991. Paradigma Islam, Interpretasi untuk aksi. Bandung. Penerbit Mizan.

Kuntowijoyo.1999. Budaya dan Masyarakat. Yogyakarta: Tiara Wacana Yogya.. 
Paeni, Mukhlis. 2009. Sejarah Kebudayaan Indonesia: Bahasa, Sastra Dan Aksara. Jakarta: Raja Grafindo Persada

Rukmi, Maria Indra. 2004. Naskah-Naskah di Lombok Ditulis Dalam Sastra Melayu Lintas Daerah. Jakarta: Pusat Bahasa Departemen Pendidikan Nasional.

Salam, Solichin (Editor). 1979. Deskripsi Aliran Keprcayaan Wetu Telu di Pulau Lombok, Jakarta: Badan Penelitian dan Pengembangan Depag. RI.

Sendjaja, Sasa Djuarsa. 1993. Pengantar Komunikasi. Jakarta. Universitas Terbuka.

Suhardi, Dkk. 2010. Upacara Daur Hidup Suku Sasak. Mataram. Pustaka Widya.

Syaikh Ahmad Ibnu Muhammad Yunus. Daqoiqul Ahbar.

Syaikh Muhammad Sholih Bin Abdulloh Minangkabau. 1356 H. Kasful Asror. Al Hamdiah.

Syam, Nur. 2008. Islam Lokal: Akulturasi Islam di Bumi Sasak. Lombok Tengah: STAIIQH Press.

Syukur, Abdul Ghani dkk. 1992. Nur Muhammad Menyingkap Asal Mula Kejadian Makhluk (Terjemah Daqoiqul Ahbar). Bandung: Husaini Bandung.

Tjandrasasmita, Uka. (Editor). 1993. Jaman Pertumbuhan dan Perkembangan Kerajaan-Kerajaan Islam di Indonesia. Sejarah Nasional Indonesia III. Edisi ke-4. Jakarta: Departemen Pendidikan dan Kebudayaan. PN. Balai Pustaka.

Wacana, Lalu. dkk. 1978. Sejarah Daerah Nusa Tenggara Barat. Jakarta: Depdikbud.

Zakaria, Fathurrahman. 1998. Mozaik Budaya Orang Mataram. Mataram: Sumur Mas. 